Jurnal Konstruksi Hukum | ISSN: XXXX | E-ISSN: XXXX Vol. 1, No. 2, Oktober 2020, Hal. 421-425| Available Online at https://www.ejournal.warmadewa.ac.id/index.php/jukonhum DOI: https://doi.org/10.22225/jkh.1.2.2535.421-425

\title{
KEWENANGAN NOTARIS TERHADAP PEMBUATAN COVERNOTE
}

\author{
I Made Ari Nurjaya, I Nyoman Sumardhika, Ida Ayu Putu Widiati \\ Fakultas Hukum Universitas Warmadewa, Denpasar - Bali, Indonesia
}

\begin{abstract}
Abstrak
Salah satu produk hukum yang dibuat oleh notaris sebagai bagian dari kewenangannya adalah akta, baik bersifat akta autentik maupun akta di bawah tangan. Selain akta otentik dan akta di bawah tangan, notaris juga dapat mengeluarkan surat keterangan yang lazimnya disebut dengan istilah covernote. Surat keterangan atau covernote merupakan suatu keterangan atau catatan yang berupa informasi bahwa surat-surat kepemilikan atas tanah sedang dalam proses pembuatan sertifikat atas tanah yang dikiatkan karena suatu proses roya, balik nama atas kepemilikan tanah dan pemecahan terhadap satu sertifikat menjadi dua sertifikat. Penelitian ini mengkaji dua hal terkait kewenangan notaris, yakni dasar kewenangan notaris dalam mengeluarkan covernote dan akibat hukum dari pembuatan covernote oleh notaris. Kajian ini menggunakan metode penelitian hukum normatif dan pendekatan konseptual serta pendekatan perundang-undangan. Hasil penelitian menunjukkan covernote yang dikeluarkan oleh notaris sesungguhnya merupakan surat keterangan biasa, bukan merupakan produk hukum notaris. Covernote hanya berisi penjelasan mengenai akta yang sedang dalam proses pensertifikatan belum selesai dan akan diselesaikan dalam jangka waktu yang telah ditentukan oleh notaris itu sendiri, sehingga covernote tidak mengikat secara hukum. Notaris berwenang dalam membuat covernote hanya saja tidak diatur dalam peraturan perundang-undangan sehingga, jika disimpulkan, covernote bukan merupakan produk hukum notaris. Akibat hukum bagi Notaris jika gagal dalam melaksanakan covernote, mereka dapat dimintakan pertanggungjawaban agar segera menyelesaikannya. Akibat hukum dari tidak terpenuhinya isi dari covernote ialah berupa pelanggaran terhadap Pasal 1366 KUHPer karena notaris dianggap lalai dalam menjalankan tugas dan kewenangannya.
\end{abstract}

Kata Kunci: Covernote; Kewenangan; Notaris

\begin{abstract}
One of the legal products made by notary as a part of their authorities is a deed, both authentic deeds and underhand-made deeds. In addition to these deeds, a notary also has the authority to issue a certificate which is commonly referred to as a covernote. A certificate or covernote is a statement or note in the form of information confirming that a land ownership deed is in the process of a certificate making that is due to a process of roya, transfer of name of land ownership and splitting of one certificate into two. This study examines two issues related to notary authority, namely the basis for the notary's authority in issuing a covernote and the legal consequences of making the covernote. This study uses a normative legal research method and a conceptual approach as well as a statutory approach. The results showed that the covernote issued by a notary was actually an ordinary certificate, not a legal product of a notary. Covernote only contains an explanation of the deed that is in the process of certification which has not been completed and will be completed within a period determined by the notary itself, so the covernote is not legally binding. The notary is authorized to make a covernote, but it is not regulated in the laws and regulations so that, if it is concluded, the covernote is not a legal product of a notary. The legal consequences for the notary if they fail to carry out the covernote, they can be held liable to solve them immediately. The legal consequence of not fulfilling the contents of the covernote is a violation of Article 1366 of the Criminal Code because notaries are considered negligent in carrying out their duties and authorities.
\end{abstract}

Keywords: Covernote; Authority; Notary

\section{PENDAHULUAN}

Hukum berperan dalam menjaga tatanan kehidupan masyarakat, sehingga pola prilaku masyarakat sesuai dengan norma atau kaidah hukum yang berlaku dalam suatu kelompok masyarakat. Hukum memelihara dan menciptakan ketertiban serta keamanan bagi warga masyarakat guna menjamin hak- 
hak, keadilan dalam kehidupan bermasyarakat. Hukum selalu tumbuh dan berkembang didalam masyarakat dan mengikuti perkembangan pola dan tatanan kehidupan masyarakat menuju masyarakat global. Dalam perkembangan hukum tersebut memerlukan kepastian hukum guna melindungi masyarakat melalui penerapan hukum yang berdasarkan kebenaran, keadilan dan kemanfaatan. Kepastian hukum yang dimaksud adalah tegaknya keadilan serta ketertiban hukum.

Ketidakpastian hukum berakibat pada kekacauan tatanan kehidupan masyarakat sehingga tidak ada batasan atau pedoman dalam setiap kegiatan masyarakat dan cendrung menimbulkan tindakan anarki (Harahap, 2006). Kepastian hukum memerlukan pelayanan yang objektif dan terpercaya sehingga hak dan kewajiban dapat terjamin dan memenuhi unsur keadilan. Salah satu ketidak pastian hukum yang dapat ditemui dalam dunia perbankan atau dalam praktik pembuatan akta oleh notaris adalah penerbitan surat keterangan atau lazimnya disebut dengan istilah covernote. Surat keterangan yang dikeluarkan oleh notaris atau covernote notaris merupakan dokumen pernyataan yang dibuat oleh notaris sebagai bukti atas kepengurusan akta sertifikat tanah atau akta lainnya yang sedang dalam proses roya, balik nama atas kepemilikan tanah, atau pemecahan sertifikat tanah menjadi dua sertifikat dan lain sebagainya. Namun dalam proses pengurusan tersebut pihak notaris belum dapat menyelesaikannya, sedangkan pihak klien dalam hal ini pemilik sertifikat atau akta ingin menggunakannya sebagai jaminan pinjaman kredit pada bank dengan diikat menggunakan hak tanggungan (Indonesia, 2015).

Untuk mempercepat proses pencairan kredit, pihak bank meminta covernote kepada notaris yang bersangkutan sebagai jaminan bahwa sertifikat tersebut akan selesai dalam jangka waktu yang telah ditentukan sesuai dengan isi dari covernote notaris. Covernote digunakan sebagai pengganti atas kekurangan bukti jaminan, karena adanya kebutuhan serta hanya menjadi bukti sementara sampai notaris menyelesaikan akta kepemilikan tanah yang sedang dalam proses kepada pihak bank. Peran serta fungsi dan kedudukan covernote tidak diatur dalam instrumen peraturan perundangan, terutama dalam Undang-Undang Nomor 2 Tahun 2014 tentang Perubahan Undang-Undang Nomor 30 Tahun 2004 tentang Jabatan Notaris (Simanjutak, 2015).

Covernote dalam dunia perbankan telah menjadi hukum kebiasaan atau customary law dan dianggap telah memiliki kekuatan mengikat yang berlaku antara para pihak. Covernote digunakan sebagai jaminan sementara dalam proses pencairan kredit sesungguhnya telah terjadi kekosongan hukum dalam pelaksanaannya, karena tidak diatur dalam peraturan perundangan dan tidak termasuk dalam produk hukum notaris. Praktik penggunaan covernote sebagai bukti jaminan sementara merupakan sebuah praktik tanpa didasari atas suatu instrumen hukum atau dapat dikatan telah terjadi kekosongan hukum dalam pelaksanaan covernote (Soerodjo, 2003). Maka perlu dipertanyakan mengenai kekuatan hukum dalam pelaksanaan covernote, mengingat tidak ada payung hukum dalam pembuatan covernote. Hal ini berkaitan mengenai tanggungjawab notaris yang membuat covernote, karena tidak ada dasar hukum pembuatan covernote maka apakah notaris bertanggungjawab atas pelaksanaan dan pembuatan covernote sebagai jaminan kredit atau tidak bertanggungjawab.

Berdasarkan uraian di atas, penelitian ini bertujuan untuk memahami keabsahan dan akibat hukum pembuatan covernote serta mengetahui tanggungjawab notaris terhadap pembuatan covernote.

\section{METODE PENELITIAN}

Penelitian ini menggunakan metode penelitian hukum normatif, yang merupakan sebuah instrumen dalam melakukan dan menentukan arah penyusunan penulisan karya tulis ilmiah (Suprapto, 2013). Penulisan hukum normatif digunakan karena terjadi kekosongan norma hukum dalam pelaksanaan pembuatan covernote oleh notaris (Fajar \& Yulianto, 2009). Pendekatan yang digunakan dalam penulisan ini adalah pendekatan perundangan dan pendekatan konsep hukum (Tanjung, 2005). Penelitian ini menggunakan data sekunder seperti literatur hukum dan karya tulis ilmiah yang dikumpulkan dan dianalisis secara kualitatif dan normatif.

\section{HASIL DAN PEMBAHASAN}

\section{Dasar Hukum dan Kewenangan Notaris dalam Pembuatan Akta}

Notaris berwenang dalam membuat akta autentik yang merupakan bagian dari produk hukum notaris. Akta autentik merupakan akta yang telah ditentukan pembuatan dan pengaturannya berdasarkan Undang-undang Jabatan Notaris, serta Pasal 1868 KUHPer, pembuktian dan kekuatan hukum akta autentik sangat jelas dan tidak dapat dipatahkan atau kecil kemungkinan bahwa akta 
autentik tersebut batal karena hukum karena pembuktian akta autentik telah dijamin oleh undangundang (Adjie, 2012). Akta dibawah tangan adalah akta yang dibuat sendiri oleh pihak-pihak tanpa bantuan pejabat umum (Makarao, 2004). Covernote sesungguhnya merupakan surat keterangan yang dibuat oleh notaris dan berkedudukan sebagai seorang Pejabat Pembuat Akta Tanah (PPAT). Covernote tidak termasuk dalam instrumen akta autentik ataupun akta dibawah tangan, artinya covernote secara hukum dan legalitasnya bukan merupakan produk hukum notaris yang sekaligus berkedudukan sebagai PPAT (Adjie, 2012). Covernote tidak ditemukan dalam instrumen peraturan perundangan (Sulihandari \& Rifiani, 2013) Covernote tidak termasuk dalam instrumen akta autentik karena tidak dipenuhinya syarat dan unsur dalam pembuatan akta autentik seperti dibuat berdasarkan peraturan perundangan dan dibuat dihadapan notaris.

Tidak ada dasar hukum dalam pembuatan covernote oleh notaris, namun covernote dibuat berdasarkan kebiasaan dengan memperhatikan aspek-aspek hukum perikatan dan perjanjian serta tidak merugikan bagi para pihak, maka covernote tidak dilarang dan termasuk dalam instrumen perikatan atau perjanjian. Oleh karena itu covernote dalam pelaksanaannya perlu memperhatikan syarat sahnya perjanjian dan perikatan.Covernote cenderung dikategorikan sebagai perikatan yang lahir karena adanya perjanjian, bukan karena undang-undang Berdasarkan Pasal 1233 Kitab Undangundang Hukum Perdata yaitu tiap-tiap perikatan dilahirkan baik karena persetujuan, baik karena undang-undang. Oleh sebab itu covernote hanya mengikat bagi para pihak yang tercantum didalamnya yakni antara notaris sebagai pelaksana dalam pembuatan akta yang belum terselesaikan dengan pihak bank yang meminta bukti jaminan sementara dalam proses permohonan kredit yang dilakukan debitur dengan jaminan sertifikat atas tanah yang sedang dalam proses pembentukan sertifikat oleh notaris.

Covernote dibuat berdasarkan kebiasaaan dan berdasarkan hukum materiil yaitu hukum perikatan. Jika sumber hukum formil berupa kebiasaan dapat diterima, tidak bertentangan dengan hukum dan dilakukan berulang kali yang menyebabkan tindakan tersebut dianggap merupakan suatu kebenaran dan tidak bertentangan dengan hukum yang telah berlaku. Covernote dikategorikan sebagai suatu perikatan dan bukan sebagai akta autentik atau akta dibawah tangan. Pembuatan covernote tidak memiliki pengaturan yang baku mengenai bentuk, tata cara, syarat yang harus dipenuhi dalam pembuatan covernote, sehingga covernote yang dibuat oleh notaris bentuknya dapat berbeda. Pada umumnya covernote memiliki kop surat dari notaris yang bersangkutan, serta mendapat pengesahan berupa cap dan tanda tangan dari notaris tersebut.

Pasal 1868 KUHPerdata mengatur mengenai akta otentik yang merupakan akta dalam bentuk yang telah ditentukan oleh undang-undang, dibuat dihadapan pegawai-pegawai umum yang berkuasa untuk itu ditempat dimana akta dibuat. Akta otentik itu sendiri dibagi menjadi 2 yaitu:

a. Akta para pihak (Partij akte) adalah akta yang membuat keterangan (berisi) apa yang dikehendaki oleh pihak-pihak yang bersangkutan. Misalnya pihak-pihak yang bersangkutan mengatakan menjual atau membeli selanjutnya pihak notaris merumuskan kehendak para pihak tersebut dalam suatu akta.

b. Akta Pejabat (Ambtelijke akte atau Akta Relas), akta yang memuat keterangan resmi dari pejabat yang berwenang. Jadi akta ini hanya memuat keterangan dari satu pihak saja, yakni pihak pejabat yang membuatnya. Akta ini dianggap mempunyai kekuatann pembuktian terhadap semua orang, misalnya akta kelahiran. Jadi Ambtelijke Akte atau Relaas Akte merupakan: inisiatif ada pada pejabat, berisi keterangan tertulis dari pejabat (ambtenaar) pembuat akta.

Akta dibawah tangan adalah akta yang dibuat sendiri oleh pihak-pihak tanpa bantuan pejabat umum untuk dijadikan alat bukti. Berdasarkan pengertian dan bentuk dari akta autentik dan akta dibawah tangan, covernote tidak termasuk dalam dua kategori akta tersebut. Covernote yang dibuat oleh notaris termasuk dalam pengertian akta pejabat, namun pengaturannya tidak menyebutkan bahwa covernote adalah akta autentik. Sehingga covernote lebih mengarah pada bentuk perikatan dan bukan juga merupakan akta dibawah tangan karena notaris sendiri yang mengeluarkan covernote tersebut, maka tidak mungkin Covernote dibuat dihadapan pejabat itu sendiri atas keterangan yang dibuatnya sendiri.

\section{Akibat Hukum Pembuatan Covernote oleh Notaris}

Kemunculan covernote diakibatkan adanya kebutuhan yang sangat mendesak dari pihak bank selaku kreditur dan debitur yang aktanya sedang dalam proses pembuatan sertifikat. Kekurangan atas bukti 
jaminan yang diperlukan dalam proses permohonan kredit memaksa pihak bank untuk meminta bukti jaminan pada notaris yang digolongkan dalam bentuk perjanjian bahwa notaris harus dapat menyelesaikan kepengurusan akta debitur sesuai dengan jangka waktu yang telah ditentukan dalam kesepakatan tersebut yang lebih dikenal dengan covernote. Dengan covernote yang dikeluarkan oleh notaris maka notaris harus dapat mempertanggungjawabkan isi dari covernote tersebut. Dengan adanya jaminan bahwa covernote yang dikeluarkan notaris dapat dipertanggungjawabkan maka pihak kreditur menjadikannya bukti jaminan sementara hingga proses pembuatan sertifikat selesai dan bukan sebagai jaminan dalam permohonan kredit. Jika notaris tidak mampu memenuhi isi dari covernote maka notaris tersebut harus mempertanggungjawabkannya dengan segera menyelesaikan sertifikat atas tanah, namun notaris tidak dapat diberikan sanksi administrasi sesuai dengan UndangUdang Jabatan Notaris karena covernote tidak diatur dalam undang-undang tersebut. Namun notaris memiliki beban sosial karena dianggap lalai dalam menjalankan kewajibannya sehingga menyebapkan penurunan kepercayaan masyarakat terhadap notaris tersebut.

Jika Notaris belum mampu menjalankan isi covernote sesuai dengan yang diharapkan maka Notaris meminta perpanjangan waktu untuk menyelesaikannya. Terkait dengan persoalan selama ini yang timbul akibat covernote, jika Notaris secara berulangkali belum mampu melaksanakan isi covernote sesuai dengan yang diharapkan, maka sanksi yang diterima biasanya adalah sanksi moral berupa rasa kepercayaan dari pihak bank mulai berkurang dan berujung pada pengalihan kepercayaan kepada Notaris lain (Sjaifurrachman \& Adjie, 2011). Notaris dituntut untuk senantiasa bertanggung jawab jika ternyata gagal dalam menjalankan isi covernote tersebut. Karena pada dasarnya lahirnya covernote tersebut adalah hasil dari kesepakatan atau perjanjian antara bank dengan Notaris, di mana Notaris bersedia untuk menjalankan apa yang diminta oleh bank dalam melakukan atau membuat suatu perbuatan hukum seperti pembuatan akta perjanjian kredit, pembuatan akta pemberian hak tanggungan atau pengikatan jaminan sertifikat hak milik. Akibat hukum bagi notaris jika gagal dalam melaksanakan covernote, maka Notaris dapat dimintakan pertanggungjawaban untuk segera menyelesaikannya. Berdasarkan kesepakatan antara kedua belah pihak, Notaris dapat meminta perpanjangan waktu untuk menyelesaikan isi covernote tersebut. Jika ada permasalahan yang terkait dengan penerbitan dan pelaksanaan covernote, biasanya sanksi yang diberikan bagi notaris adalah sanksi moral berupa adanya ketidakpercayaan bank kepada Notaris karena Notaris tidak dapat menyelesaikan apa yang menjadi isi dari covernote seperti yang diharapkan. Notaris dianggap telah gagal memenuhi ketentuan Pasal 1366 KUHPer jika kelalaian tersebut disebabkan atas kesalahan notaris dalam menjalankan dan melaksanakan isi Covernote.

\section{SIMPULAN DAN SARAN Simpulan}

Covernote bukanlah akta autentik karena tidak diatur dalam instrumen peraturan perundangan, dan tidak sesuai dengan syarat yang harus dipenuhi dalam membuat akta autentik maupun akta dibawah tangan. Covernote dibuat berdasarkan kebiasaan dan tergolong sebagai bentuk perikatan yang lahir karena perjanjian, bukan karena undang-undang. Covernote digolongkan mempunyai sumber hukum formil yaitu berdasarkan kebiasaan dan sumber hukum materiil berdasarkan sah nya perjanjian. Akibat hukum bagi Notaris jika gagal dalam melaksanakan covernote, maka Notaris dapat dimintakan pertanggungjawaban untuk segera menyelesaikannya. Berdasarkan kesepakatan antara kedua belah pihak, Notaris dapat meminta perpanjangan waktu untuk menyelesaikan isi covernote tersebut. Jika ada permasalahan yang terkait dengan penerbitan dan pelaksanaan covernote, biasanya sanksi yang diberikan bagi notaris adalah sanksi moral berupa adanya ketidakpercayaan bank kepada Notaris karena Notaris tidak dapat menyelesaikan apa yang menjadi isi dari covernote seperti yang diharapkan.

\section{Saran}

Mengingat praktik pembuatan covernote dalam dunia kenotariatan tidak dapat dihindari dan telah menjadi kebiasaan, maka disarankan kepada Ikatan Notaris Indonesia untuk membuat suatu instrumen aturan mengenai pembuatan covernote, prosedur, tata cara dan batasan dari penggunaan covernote tersebut. Perlu dilakukan pengawasan terhadap penggunaan covernote serta penjelasan mengenai keabsahan dan keberlakuan covernote kepada pihak bank dan debitur yang memohon melakukan pinjaman kredit. Disarankan kepada pihak notaris agar covernote dibuat dengan prinsip kehati-hatian 
sehingga tidak terdapat pihak yang dirugikan atas dibuatnya covernote. Jangka waktu dari pembuatan atau keberlakuan covernote perlu ditentukan dan disepakati oleh para pihak.

\section{DAFTAR PUSTAKA}

Adjie, H. (2012). Bernas-Bernas Pemikiran di Bidang Notaris dan PPAT. Bandung: Mandar Maju. Fajar, M., \& Yulianto, A. (2009). Dualisme Penelitian Hukum Normatif. Yogyakarta: Pustaka Pelajar. Harahap, M. Y. (2006). Pembahasan Permasalahan dan Penerapan KUHAP. Jakarta: Sinar Grafika. Indonesia, B. (2015). Kamus Bank Indonesia (Serial Onl).

Makarao, T. (2004). Pokok-Pokok Hukum Acara Perdata. Jakarta: PT. Rineka Cipta.

Simanjutak, P. N. H. (2015). Hukum Perdata Indonesia. Jakarta: PT Kharisma Putera Utama.

Sjaifurrachman, \& Adjie, H. (2011). Aspek Pertanggungjawaban Notaris dalam Pembuatan Akta. Bandung: Mandar Maju.

Soerodjo, I. (2003). Kepastian Hukum Hak Atas Tanah di Indonesia. Surabaya: Arkola.

Sulihandari, H., \& Rifiani, N. (2013). Prinsip-Prinsip Dasar Profesi Notaris. Jakarta: Dunia Cerdas.

Suprapto. (2013). Metodologi Penelitian dan Ilmu-Ilmu Pengetahuan Sosial. Bogor: CAPS.

Tanjung, B. N. (2005). Pedoman Penulisan Karya Ilmiah. Medan: Kencana. 